\title{
Green certified shopping malls undertaken by foreign contractors in Russia: A comparative qualitative study
}

\author{
H.G. Bayhan*1, G. Polat ${ }^{2}$ \\ ${ }^{1}$ Sakarya University of Applied Sciences, Department of Civil Engineering, Sakarya, Turkey \\ ${ }^{2}$ Istanbul Technical University, Department of Civil Engineering, Istanbul, Turkey
}

\begin{abstract}
In recent years, environmental issues have become one of the main concerns of the construction sector. Green buildings are recognized as an important step towards these issues by construction professionals. However, this situation creates new challenges for companies providing contracting services in foreign countries. Today, designing and constructing projects that comply with the requirements of green building certification systems increase the prestige and profit of both the project owner and the contractor. In this study, the green building certification process of two shopping mall projects, which were certified with the Ecostandard green certification system in the Moscow city held by foreign contractors, is investigated. A comparative qualitative case study methodology has been employed to gain a better understanding of the critical success factors of the certification process. A novel SWOT analysis framework is used to comprehensively understand the differences between these two shopping mall projects. The lack of systems for ecological management, outdoor lighting and minimize light pollution, renewable energy sources, material and waste management have been found as the major weaknesses of these projects. On the other hand, architectural planning and design solutions, site selection, infrastructure, and landscaping have been found as strengths. Also, semi-structured interviews were conducted to put forward opportunities and threats. The outcomes of this study are expected to guide construction professionals in the new construction certification process of mall projects. Moreover, the proposed outcomes can be employed to investigate residential or commercial buildings with green certification built by foreign contractors in the future.
\end{abstract}

\section{Keywords}

Green building certification; Russia; Developing countries; Qualitative; Sustainability; SWOT

Received: 30 May 2019; Accepted: 21 June 2019

ISSN: 2630-5771 (online) (C) 2019 Golden Light Publishing All rights reserved.

\section{Introduction}

Means and methods of construction have a great influence on the built environment as well as the quality of living spaces. The construction industry has an excessive effect on the environment; it is responsible for the production of $35-40 \%$ of $\mathrm{CO} 2$ emissions and solid waste, the consumption of $40 \%$ of total energy and raw materials, $70 \%$ of electricity, and the usage of $16 \%$ of water worldwide [1-4]. Green building certification systems are recognized as innovative solutions to decrease this environmental burden originated from buildings internationally. From this global perspective, developing countries have been amongst the most important influencers of environmental burden in the construction industry as they have huge requirements for infrastructure

\footnotetext{
Corresponding author

Email: hgbayhan@sakarya.edu.tr
} 
development to support growth and improve living standards [5]. Therefore, green certified projects undertaken in developing countries are to be carefully examined to spread green building assessments and solutions.

Green buildings are structures that carefully consider environmental measures, human comfort and resource efficiency throughout their life-cycle; from design to deconstruction [6,7]. Green buildings improve the prestige of companies and comfort of customers/users, this way increased profit ensures investor satisfaction [8]. Certification is the key to label a green building. There are various kinds of local and international certification systems that have different values to measure the greenness index [9]. From England, Building Research Establishment Environmental Assessment Method (BREEAM) and American Leadership in Energy and Environmental Design (LEED) are the most widely used green building certification systems today [10]. However, the fact that these certification systems are not always satisfactory in terms of price, country objectives and adaptation into the local legal system or regulations has led developing countries to shape new certification systems according to their requirements.

The commercial building sector is crucial in order to adapt to sustainable development objectives for the countries. Commercial buildings, like shopping malls, are ranked as the highest energy consuming buildings [11,12]. When building master plans for green/smart cities, certifying the city's epitomic structures such as shopping malls will increase the level of awareness and the popularity of the green market. Green building certification has become preferred for this kind of buildings in order to improve various measures such as; the quality and comfort of the user and environment, use of natural sources rationally, prevent pollution, reduction in waste, and use energy efficiently while encouraging the use of renewable energy resources [13].

In this study, green building systems in Russia have been summarized and two shopping mall projects held in the Moscow city are compared relatively according to their points obtained from the Ecostandard green building certification system. This way, the root causes of the missing points are discovered and lessons learned from these two projects are intended to be implemented in future projects. Also, it is aimed to explain the difficulties for foreign contractors that are aiming to take green certification from a local community. An exploratory SWOT methodology is used for the study.

\section{Green building potential in Russia}

In recent years, Russia's social and economic growth shifted the country's economy to the next level; Russia ranked second at the developing countries list after China [14], and it is expected that the country is going to be getting ahead of Germany and the UK and become the 5th biggest economy in 2020 [15]. With this economic growth trend, set of goals on sustainable development and building practices were amongst the most important titles in the report for RIO +20 [16]. The Russian government's new political stance on sustainability could also be understood by decisions in other sectors other than the construction, such as to ensure the maintenance of forests and reforestation of all cut-down and dead forests [17].

Current president of Russian Federation, Vladimir Putin, gave an inspirational speech that underlines that more than $50 \%$ of world population is now living in cities and in Russia, this ratio is around $75 \%$, and the key to the development of cities of the future lies in harmony between the technical sphere and nature, in 2018 Moscow Urban Forum [18]. According to the country's sustainable development missions, construction is one of the major industries in dire need of change. Construction facilities are responsible for $67 \%$ of electric energy, $40 \%$ of raw materials consumption in Russia [19].

Gennadievna-Pahomova et al. [20] argued that factors like the cost of energy resources in the country are 2-4 times lower than in Europe, lack of government support and unclear understanding in ecologically-responsible construction resulted with the lack of interest in both manufacturers of green 
building products and their end users. However, a growing market like Russia creates a favorable environment in green buildings. Many local companies have changed their vision to sustainable building practices with the Olympics in Sochi that boosted the awareness in 2014. After the first examples of green buildings certified by BREEAM and LEED, Russian ecology-construction related certification systems started to appear. Green Construction Board (GCB) supported by State Ministry of Regional Development, Green Standards - Ecology Ranking Center (ECR) developed by Ministry of Natural Resources, and Ecology to rank Olympic Games facilities, NOSTROY developed by non-profit engineering partnership AVOK, and GOST R 54964-2012 which is Russian state requirement valid from the 1st of March on 2013, are the steps of the development of a local certification system [21]. Lately, Green Zoom, based on the 4th version of the LEED system, founded by an autonomous nonprofit organization in 2015, could be favored in the country.

The capital of the country, Moscow, is experiencing the new urban expansion program [22]. Green building concept is one of the most crucial features of this sustainable expansion. A local Muscovite firm, called Ecostandard Group of Companies, founded an internationally accepted green building certification system; Ecostandard. The group was established in 1997 on the basis of a number of leading scientific centers in Moscow, including the natural faculties of the Moscow State University [23]. The institution is a member of United States Green Building Council (USGBC) that enhances the validity of the certification internationally. The Russian Green Building Certificate become legalized in April 2013, is functional especially for Russia and compatible with other internationally accepted certifications.

Large-scale projects pursuing sustainable development measures in Moscow attracts not only local firms but foreign construction firms. Payments in dollar currency increase the interest of foreign companies having inflation issues [24]. Qualified projects like shopping malls need expertise, the ability to consider environmental measures and enhance the intended quality. Foreign companies possessing the expertise, international prestige, technological know-how, the relevant knowledge about Russian legislation, and close relationship with the Russian market and stakeholders are remained ahead in winning a new tender [25]. Moreover, measuring and reporting on environmental impact, setting targets and carrying out improvements and green building related expertise is a step forward for the foreign companies in the last decade [26].

\section{Method}

SWOT analysis in one of the most popular techniques for exposing the strategic cases considering internal (strengths and weaknesses) and external environment (opportunities and threats) and therefore analyzing the current and upcoming situations [27]. Its frameworks are developed in the early 1960s by Harvard Business School faculty [28,29]. The practicality and simplicity are two prominent functions that led to wide use of the SWOT analytical tool in the social sciences [30]. One of the superior features of the methodology is its adaptation capability to upcoming concepts and evaluations.

For this study, a novel SWOT methodology approach is used by considering the 10-point scale of the studied certification rating system and the category interpretations regarding which internal or external environment group that is going to be evaluated with the industry professionals. The interchangeable and derivable structure of the SWOT analysis fit both external and internal factors to interpret the scorecards, where in the adopted approach, strength and weaknesses are accepted as Internal; opportunities and threats are accepted as External measures. The categories with low points (0-2) are matched with internal weaknesses, (3-4) with external threats, (5-7) with external opportunities and (8-10) with internal strengths and interpreted accordingly, could be followed from Fig. 1. By this, a common framework is put forward to group and measure the success of the categories from internal and external perspectives and 
understand the green certification success of projects accurately with the expert opinions. First, a profound literature review with the green building certification systems used in Russia is conducted. After this, the Ecostandard certification is confirmed suitable as a Russian local certification system and familiar to foreign construction companies because of its membership to USGBC. Hence in this study, the two certified green building projects undertaken by a foreign construction firm are evaluated within the framework by interpretations of their scorecards according to the Ecostandard certification guide and the interviews with four different industry professionals who actively participated in these projects at the certification process. The interviewed professionals are selected according to their level of responsibility, knowledge, and eligibility who have administrative positions for both projects. Three of the interviewees were from the contractor company; the project manager who is responsible for the construction activities as well as the information exchange with stakeholders and certification body, the facility manager/mechanical engineer who is the head of technical activities such as the selection of mechanical and HVAC systems representing the utmost importance for the energy and atmosphere related evaluations, and the architect who is a member of the design team. The fourth interviewee is from certification company which is also at the administrative level who is responsible for the organizing of certification documents. All in all, it is considered important to apply the SWOT methodology to profoundly understand the assessments from different perspectives for better managerial decisions.

\subsection{Case study}

In the case study, two shopping mall projects undertaken by the same foreign contractor in the Moscow city are examined. Turn-key design, procurement, construction, testing and commissioning and start up is held by the same contractor for both projects, where these projects have an area of 196,750 $\mathrm{m}^{2}$ (Project A) and 245,000 $\mathrm{m}^{2}$ (Project B), respectively (Fig. 2). Project A took 32 months to be completed and finished in 2018, where Project B is completed in 51 months and finished in 2015 .

\begin{tabular}{|c|c|c|c|c|c|c|c|c|c|c|}
\hline \multicolumn{8}{|c|}{ Point Scale to Interpret SWOT Analysis } \\
\hline \multicolumn{3}{|c|}{ Strengths } & \multicolumn{2}{|c|}{ Opportunities } & Threats & \multicolumn{3}{|c|}{ Weaknesses } \\
\hline 10 & 9 & 8 & 7 & 6 & 5 & 4 & 3 & 2 & 1 & 0 \\
\hline \multicolumn{3}{|c|}{ INTERNAL } & \multicolumn{3}{|c|}{ EXTERNAL } & \multicolumn{3}{|c|}{ INTERNAL } \\
\hline
\end{tabular}

Fig. 1. Point scale to interpret SWOT analysis for shopping mall project A and B

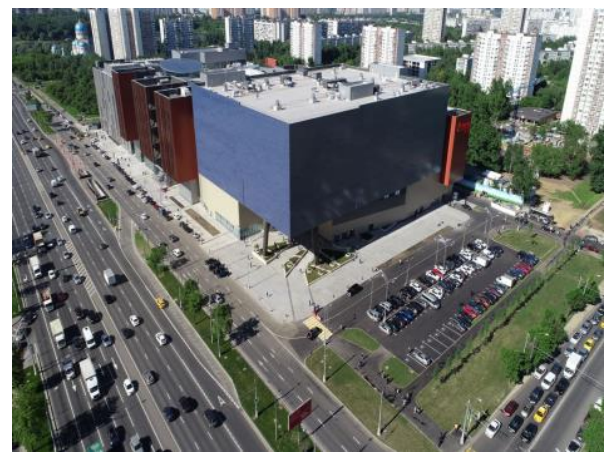

(a) Project A

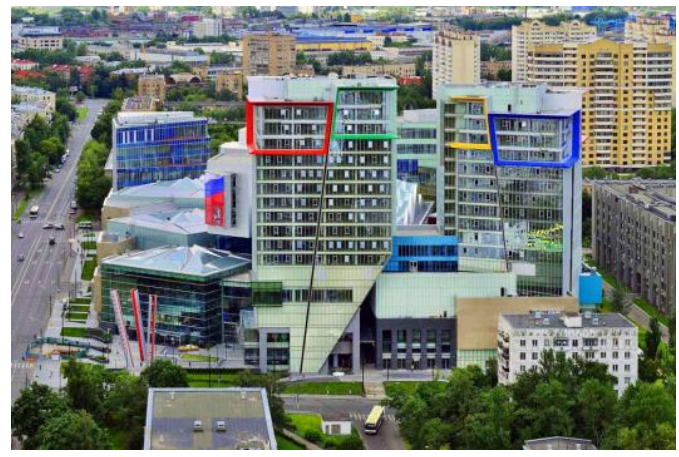

(b) Project B

Fig. 2. Shopping mall project A and B 
The points received from Ecostandard could be followed from Table 1. In the certification, potential points are related to the number of subcategories and levels are earned according to success ratios of subcategories. Both projects are awarded a "Gold" certification level as their final evaluation ratios are in between 60\%-79\%. However, there are differences and similarities are examined with SWOT methodology to improve the points for the upcoming projects. SWOT methodology is interpreted according to the points earned and the results of interviews with professionals. In total, eight subcategories are examined in detail.

\subsubsection{Ecological management (EM)}

Ecological management is crucial in terms of green building practices and represents over $13 \%$ of the total points. In this category, both projects have taken the exact same points from the matching subheadings. According to results (Table 2), professionals need to put greater emphasize on developing ecological management systems in accordance with GOST systems (national standards of the Russian Federation and Commonwealth of Independent States countries), storm sewage design and increase the number of certified specialists. Both projects could not receive a single point from subcategory 1.1 that consider the ecological management system.

Table 1. The results of green building assessment for shopping mall project A and B

\begin{tabular}{|c|c|c|c|c|c|c|}
\hline \multirow[b]{2}{*}{ No } & \multirow[b]{2}{*}{ Category Name } & \multirow{2}{*}{$\begin{array}{l}\text { Potential } \\
\text { Points }\end{array}$} & \multicolumn{2}{|c|}{ Project A } & \multicolumn{2}{|c|}{ Project B } \\
\hline & & & $\begin{array}{l}\text { Points } \\
\text { Received }\end{array}$ & Success $(\%)$ & $\begin{array}{l}\text { Points } \\
\text { Received }\end{array}$ & Success $(\%)$ \\
\hline 1 & Ecological Management (EM) & 70 & 44 & 62,86 & 44 & 62,86 \\
\hline 2 & $\begin{array}{l}\text { Site selection, Infrastructure and } \\
\text { Landscaping (SIL) }\end{array}$ & 80 & 66 & 82,5 & 70 & 87,5 \\
\hline 3 & $\begin{array}{l}\text { Rational use of water, Storm water } \\
\text { and Prevent pollution (RSP) }\end{array}$ & 40 & 21 & 52,5 & 27 & 67,5 \\
\hline 4 & $\begin{array}{l}\text { Architectural planning and Design } \\
\text { solutions (AD) }\end{array}$ & 100 & 79 & 79 & 83 & 83 \\
\hline 5 & Energy Saving and Efficiency (EE) & 70 & 45 & 64,29 & 38 & 54,29 \\
\hline 6 & Material and Waste (MW) & 80 & 20 & 25 & 11 & 13,75 \\
\hline 7 & $\begin{array}{l}\text { Quality and Comfort of the } \\
\text { environment (QC) }\end{array}$ & 60 & 42 & 70 & 34 & 56,68 \\
\hline \multirow[t]{2}{*}{8} & Health and Safety (HS) & 30 & 18 & 60 & 18 & 60 \\
\hline & Final Evaluation & 530 & 335 & 63,21 & 325 & 61,32 \\
\hline
\end{tabular}

Table 2. SWOT analysis of ecological management category

\begin{tabular}{|c|c|c|}
\hline No & SWOT & Project A and B [Subcategory] \\
\hline EM1 & $\begin{array}{l}\text { Strengths } \\
(\text { EM) }\end{array}$ & $\begin{array}{l}\text { - Ability to plan landscape arrangement and prevention for natural hazards. [1.3 and 1.4] } \\
\text { - Reliable contact with citizens for the development of the territory. [1.6] }\end{array}$ \\
\hline EM1.2 & $\begin{array}{l}\text { Weaknesses } \\
\qquad(\text { EM) }\end{array}$ & $\begin{array}{l}\text { - There is no ecological management system in accordance with GOST R ISO 14001-2007. } \\
\text { [1.1] }\end{array}$ \\
\hline EM1.3 & $\begin{array}{l}\text { Opportunities } \\
\text { (EM) }\end{array}$ & $\begin{array}{l}\text { - Develop a better plan of nature protection measures at the stages of the life cycle in } \\
\text { accordance with GOST R ISO } 14042 \text { - 2001. [1.2] } \\
\text { - More than preparatory work for the plan for the regulation of storm sewage could be } \\
\text { developed. [1.5] }\end{array}$ \\
\hline EM1.4 & $\begin{array}{l}\text { Threats } \\
\text { (EM) }\end{array}$ & $\begin{array}{l}\text { - Only one certified specialist to assess the suitability of the property and develop } \\
\text { documentation in the construction phase (Better to work with two certified specialists - } 7 \\
\text { points addition). [1.7] }\end{array}$ \\
\hline
\end{tabular}


3.1.2. Site selection, infrastructure, and Improvements in the gardening volume, greening landscaping (SIL) of the roof and bicycle path connections are found

Minimization of landscape risks in the selection of a site for construction and its further development and greening the roof of building subcategories possess differences in these projects (Table 3). necessary for both projects. The construction territory could be selected higher than 1.5 meters for the possibility of flooding at Project A.

Table 3. SWOT analysis of site selection, infrastructure and landscaping category

\begin{tabular}{|c|c|c|c|}
\hline No & $\begin{array}{c}\text { SWOT } \\
\text { (Category) }\end{array}$ & Project A [Subcategory] & Project B [Subcategory] \\
\hline $\begin{array}{c}\text { SIL } \\
2.1\end{array}$ & $\begin{array}{l}\text { Strengths } \\
\text { (SIL) }\end{array}$ & $\begin{array}{l}\text { - Choosing an appropriate site for construction } \\
\text { (According to Red book), territory requires } \\
\text { reclamation and public utilities are existing. } \\
\text { [2.1] } \\
\text { - Social infrastructure is optimized (10 main } \\
\text { types of social facilities within } 800 \text { meters } \\
\text { and pedestrian accessibility). [2.3] } \\
\text { - Public transformation and bicycle } \\
\text { parking/storage facilities are available, thus } \\
\text { the bicycle path connection is far than } 1 \mathrm{~km} \text {. } \\
\text { [2.4] } \\
\text { - Parking spots are located properly, and } \\
\text { parking is free, multistory parking is } \\
\text { available. [2.5] } \\
\text { - Accessibility of facilities and optimization of } \\
\text { life-support conditions of citizens with } \\
\text { limited mobility. [2.6] }\end{array}$ & $\begin{array}{l}\text { - Choosing an appropriate site for } \\
\text { construction (According to Red book), } \\
\text { territory requires reclamation and public } \\
\text { utilities are existing. [2.1] } \\
\text { - According to the data presented, the site is } \\
\text { approximately } 45 \mathrm{~m} \text { above the flood level in } \\
\text { the last } 100 \text { years. However, measures could } \\
\text { be envisaged to reduce zones of high- } \\
\text { temperature amplitudes. [2.2] } \\
\text { - Social infrastructure is optimized (10 main } \\
\text { types of social facilities within } 800 \text { meters } \\
\text { and pedestrian accessibility). [2.3] } \\
\text { - Public transformation and bicycle } \\
\text { parking/storage facilities are available, thus } \\
\text { the bicycle path connection is far than } 1 \mathrm{~km} \text {. } \\
\text { [2.4] } \\
\text { - Parking is free, multistory parking is } \\
\text { available. [2.5] } \\
\text { - Accessibility of facilities and optimization } \\
\text { of life-support conditions of citizens with } \\
\text { limited mobility. [2.6] }\end{array}$ \\
\hline $\begin{array}{l}\text { SIL } \\
2.2\end{array}$ & $\begin{array}{l}\text { Weaknesses } \\
\quad \text { (SIL) }\end{array}$ & - & - \\
\hline $\begin{array}{l}\text { SIL } \\
2.3\end{array}$ & $\begin{array}{l}\text { Opportunities } \\
\text { (SIL) }\end{array}$ & $\begin{array}{l}\text { - The construction territory could be selected } \\
\text { higher than } 1.5 \mathrm{~m} \text { for floods and measures } \\
\text { could be envisaged to reduce zones of high- } \\
\text { temperature amplitudes at the site for } \\
\text { construction [2.2] } \\
\text { - Compensatory planting is implemented and } \\
\text { plants were selected according to the site } \\
\text { characteristics. However, gardening is } \\
\text { implemented for only } 1360 \mathrm{~m}^{2}, \text { need to be } \\
\text { sized more than } 5 \text { times. [2.7] }\end{array}$ & $\begin{array}{l}\text { - Compensatory planting is implemented and } \\
\text { plants were selected according to the site } \\
\text { characteristics. However, gardening is } \\
\text { implemented for only } 1400 \mathrm{~m}^{2} \text {, need to be } \\
\text { sized more than } 4 \text { times. [2.7] } \\
\text { - Greening level of the roof could be raised to } \\
\% 50 \text { from } \% 37 \text { and } 3 \text { missing points could } \\
\text { be taken. [2.8] }\end{array}$ \\
\hline $\begin{array}{l}\text { SIL } \\
2.4\end{array}$ & $\begin{array}{c}\text { Threats } \\
\text { (SIL) }\end{array}$ & $\begin{array}{l}\text { There is some level of greening activity for } \\
\text { the roof, however, if the arrangement was } \\
\text { made more than } 50 \% \text { of the area of the roof } \\
\text { with greenery, } 7 \text { points could be claimed. } \\
\text { [2.8] }\end{array}$ & - \\
\hline
\end{tabular}


3.1.3. Rational use of water, storm water and prevent pollution (RSP)

Rational use of water is one of the most important components of green certification systems internationally [31]. However, in Ecostandard, it is represented by only over $7 \%$ of the total potential points. A system for collecting stormwater, wastewater treatment for landscape irrigation, use of environmentally friendly anti-icing agents have not been introduced for landscapes in both projects. Also, reducing stormwater management after the project is not fulfilled for both projects. The precautions against these measures would bring better points in upcoming projects. Project A could not receive a single point from subcategory 3.2 (Table 4).
3.1.4. Architectural planning and design solutions (AD)

Architectural planning and design are one of the strongest features for certification of both projects with the greatest overall contribution $(31,7 \%$ for Project A and \%34,3 for Project B). However, architectural or design solutions to noise preventions are not supplied. No precaution has taken to minimize light pollution from outdoor lighting systems and measures to protect mutually buildings and birds are missing. Project B could not receive any points from subcategory 4.3 could be followed from Table 5 .

Table 4. SWOT analysis of rational use of water, storm water and prevent pollution category

\begin{tabular}{|c|c|c|c|}
\hline No & $\begin{array}{c}\text { SWOT } \\
\text { (Category) }\end{array}$ & Project A [Subcategory] & Project B [Subcategory] \\
\hline $\begin{array}{c}\text { RSP } \\
3.1\end{array}$ & $\begin{array}{l}\text { Strengths } \\
\text { (RSP) }\end{array}$ & $\begin{array}{l}\text { - The export of waste for disposal at the landfill } \\
\text { hazardous waste management, the temporary san } \\
\text { use of environmentally friendly anti-icing agent }\end{array}$ & $\begin{array}{l}\text { is carried out the licensed organization for } \\
\text { itary sewer system is provided. However, the } \\
\text { s is not used. [3.4] }\end{array}$ \\
\hline $\begin{array}{c}\text { RSP } \\
3.2\end{array}$ & $\begin{array}{l}\text { Weaknesses • } \\
\quad \text { (RSP) }\end{array}$ & $\begin{array}{l}\text { - A system for collecting stormwater, } \\
\text { wastewater treatment for landscape irrigation } \\
\text { has not been introduced. Smart controllers, } \\
\text { plants that do not require watering or } \\
\text { technology for the minimization of drinking } \\
\text { water consumption is not present for } \\
\text { landscape. [3.2] }\end{array}$ & \\
\hline $\begin{array}{c}\text { RSP } \\
3.3\end{array}$ & $\begin{array}{l}\text { Opportunities } \\
\text { (RSP) } \\
\bullet\end{array}$ & $\begin{array}{l}\text { Measures to reduce stormwater runoff are } \\
\text { satisfactory. However, after the construction, } \\
\text { the stormwater amount exceeds the amount } \\
\text { before construction. [3.1] } \\
\text { The systems of collecting stormwater and } \\
\text { wastewater treatment for domestic use could } \\
\text { be installed. [3.3] }\end{array}$ & $\begin{array}{l}\text { Measures to reduce stormwater runoff are } \\
\text { satisfactory. However, after the } \\
\text { construction, the stormwater amount } \\
\text { exceeds the amount before construction. } \\
\text { [3.1] } \\
\text { Smart controllers, plants that do not } \\
\text { require watering or technology for the } \\
\text { minimization of drinking water } \\
\text { consumption is implemented. However, a } \\
\text { system for collecting stormwater, } \\
\text { wastewater treatment for landscape } \\
\text { irrigation has not been introduced for } \\
\text { landscape. [3.2] } \\
\text { The systems of collecting stormwater and } \\
\text { wastewater treatment for domestic use } \\
\text { could be installed. [3.3] }\end{array}$ \\
\hline $\begin{array}{c}\mathrm{RSP} \\
3.4\end{array}$ & $\begin{array}{r}\text { Threats } \\
\text { (RSP) }\end{array}$ & - & - \\
\hline
\end{tabular}


Table 5. SWOT analysis of architectural planning and design solutions category

\begin{tabular}{|c|c|c|c|}
\hline No & $\begin{array}{c}\text { SWOT } \\
\text { (Category) }\end{array}$ & Project A [Subcategory] & Project B [Subcategory] \\
\hline $\begin{array}{l}\mathrm{AD} \\
4.1\end{array}$ & $\begin{array}{l}\text { Strengths } \\
\text { (AD) }\end{array}$ & $\begin{array}{l}\text { - Orientation and space-planning } \\
\text { decisions of the property provide } \\
\text { a sufficient level of insolation } \\
\text { premises, provide a reduction in } \\
\text { the adverse effects of wind and } \\
\text { solar radiation. [4.2] } \\
\text { - Natural lighting is applied in most } \\
\text { of the areas. Also, architectural } \\
\text { planning and design solutions } \\
\text { provide an optimal external view } \\
\text { and create a favorable relationship } \\
\text { between the internal space and the } \\
\text { external environment (large } \\
\text { glazed surfaces) [4.4] } \\
\text { - Lamps have visors and lenses to } \\
\text { prevent undesirable propagation } \\
\text { of light, LED lights used. [4.5] } \\
\text { - Working areas are protected from } \\
\text { direct sunlight. [4.6] } \\
\text { - Greening roof and use of materials } \\
\text { with low thermal conductivity } \\
\text { reduced the heating of the roof. } \\
\text { [4.7] Flammable and hazardous } \\
\text { materials stored according to } \\
\text { engineering and planning } \\
\text { decisions to ensure safety. [4.9] }\end{array}$ & $\begin{array}{l}\text { - The export of waste for disposal at the landfill is } \\
\text { carried out the licensed organization for hazardous } \\
\text { waste management, the temporary sanitary sewer } \\
\text { system is provided. However, the use of } \\
\text { environmentally friendly anti-icing agents is not used. } \\
\text { [3.4] } \\
\text { - The object is integrated into the existing landscape, the } \\
\text { appearance and style of the building made in } \\
\text { accordance with the requirements of the Committee } \\
\text { for Architecture and Urban Planning, and the building } \\
\text { density is maintained in accordance with the GPZU. } \\
\text { [4.1] } \\
\text { - The design of the building took into account the } \\
\text { prevailing wind directions, the necessary air gaps, } \\
\text { thermal insulation, and wind insulation are provided } \\
\text { for the building envelope, also insulation is adequate. } \\
\text { [4.2] } \\
\text { - Natural lighting is applied in most of the areas. Also, } \\
\text { architectural planning and design solutions provide an } \\
\text { optimal external view and create a favorable } \\
\text { relationship between the internal space and the } \\
\text { external environment (large glazed surfaces) [4.4] } \\
\text { - Lamps have visors and lenses to prevent undesirable } \\
\text { propagation of light, LED lights used mostly. [4.5] } \\
\text { - Working areas are protected from direct sunlight. [4.6] } \\
\text { - Greening roof and use of materials with low thermal } \\
\text { conductivity reduced the heating of the roof. [4.7] } \\
\text { - The noise level is considered acceptable, where } \\
\text { architectural and design solutions are provided. [4.8] } \\
\text { - Flammable and hazardous materials stored according } \\
\text { to engineering and planning decisions to ensure safety. } \\
\text { [4.9] }\end{array}$ \\
\hline $\begin{array}{l}\mathrm{AD} \\
4.2\end{array}$ & $\begin{array}{l}\text { Weaknesses } \\
\text { (AD) }\end{array}$ & - & $\begin{array}{l}\text { - Night-light escape is not restricted and no precaution } \\
\text { has taken to minimize light pollution from outdoor } \\
\text { lighting systems. [4.3] }\end{array}$ \\
\hline $\begin{array}{l}\mathrm{AD} \\
4.3\end{array}$ & $\begin{array}{l}\text { Opportunities } \\
\text { (AD) } \\
\bullet \\
\bullet\end{array}$ & $\begin{array}{l}\text { - The building density is maintained } \\
\text { in accordance with the Urban } \\
\text { Development Plan (GPZU) but, } \\
\text { the property was not integrated } \\
\text { into the existing landscape. [4.1] } \\
\text { - Night-light escape is restricted but } \\
\text { no precaution was taken to } \\
\text { minimize light pollution from } \\
\text { outdoor lighting systems. [4.3] } \\
\text { - The noise level is considered } \\
\text { acceptable. But, architectural and } \\
\text { design solutions are not provided. } \\
\text { [4.8] } \\
\text { Protective rodent control and } \\
\text { security system used against } \\
\text { rodents and insects, but no mutual } \\
\text { precautions to protect the building } \\
\text { from birds. [4.10] }\end{array}$ & $\begin{array}{l}\text { - Protective rodent control and security system used } \\
\text { against rodents and insects, but no mutual precautions } \\
\text { to protect the building from birds. [4.10] }\end{array}$ \\
\hline $\begin{array}{l}\mathrm{AD} \\
4.4\end{array}$ & $\begin{array}{l}\text { Threats } \\
\text { (AD) }\end{array}$ & & - \\
\hline
\end{tabular}




\subsubsection{Energy saving and efficiency (EE)}

The use of renewable and waste energy is a common deficiency in this category. Also, pipes radiators and convectors, passing through the heated premises, are not isolated. Insulated pipelines are not painted twice with an anticorrosion coating and oil paint which is a specific requirement. In buildings, temperature, humidity sensors, innovative cooling techniques, and $\mathrm{CO} 2$ detectors are not used. Also, the volume of automatic lighting control systems is not sufficient. Project A could not receive points from subcategory 5.2, where project a could not receive points from both subcategory 5.2 and 5.4 (Table 6).

Table 6. SWOT analysis of energy saving and efficiency category

\begin{tabular}{|c|c|c|c|}
\hline No & $\begin{array}{c}\text { SWOT } \\
\text { (Category) }\end{array}$ & Project A [Subcategory] & Project B [Subcategory] \\
\hline $\begin{array}{l}\mathrm{EE} \\
5.1\end{array}$ & $\begin{array}{l}\text { Strengths } \\
\text { (EE) }\end{array}$ & $\begin{array}{l}\text { - Complied with the procedure and carried } \\
\text { out an inspection of commissioning for } \\
\text { energy systems. [5.1] } \\
\text { - The use of automated control systems has } \\
\text { increased the energy efficiency of heat } \\
\text { supply in the building, engineers } \\
\text { evaluated the equipment and selected } \\
\text { equipment with high energy saving. [5.3] } \\
\text { - The HVAC systems used ozone-friendly } \\
\text { refrigerants, thermostats to radiators and } \\
\text { convectors designed to reduce resource } \\
\text { consumption, relevant materials used. } \\
\text { Also, labeled pumps are efficient and } \\
\text { have no effect on the environment. [5.6] }\end{array}$ & $\begin{array}{l}\text { - Complied with the procedure and carried out } \\
\text { an inspection of commissioning for energy } \\
\text { systems. [5.1] } \\
\text { - The use of automated control systems has } \\
\text { increased the energy efficiency of heat supply } \\
\text { in the building, engineers evaluated the } \\
\text { equipment and selected equipment with high } \\
\text { energy saving. [5.3] } \\
\text { - An automated information measurement and } \\
\text { control software of the central power } \\
\text { measuring system and LED lighting is used. } \\
\text { However, \%30 of total area powered by } \\
\text { automated switching on and off luminaires, } \\
\text { depending on the natural light conditions. Still, } \\
\text { this ratio could be improved. [5.7] }\end{array}$ \\
\hline $\begin{array}{l}\mathrm{EE} \\
5.2\end{array}$ & $\begin{array}{l}\text { Weaknesses • } \\
\text { (EE) }\end{array}$ & $\begin{array}{l}\text { - The building does not use renewable or } \\
\text { waste energy. [5.2] }\end{array}$ & $\begin{array}{l}\text { - The building does not use renewable or waste } \\
\text { energy. [5.2] } \\
\text { - No technologies used to reduce heat loss } \\
\text { during transportation to the places of } \\
\text { consumption. [5.4] }\end{array}$ \\
\hline $\begin{array}{l}\mathrm{EE} \\
5.3\end{array}$ & $\begin{array}{l}\text { Opportunities } \\
\text { (EE) }\end{array}$ & $\begin{array}{l}\text { - The heating system piping is provided } \\
\text { from black steel pipes, an anticorrosive } \\
\text { coating layer, mineral wool heat } \\
\text { insulating material and covered with } \\
\text { aluminum sheet. But, pipes radiators and } \\
\text { convectors, passing through the heated } \\
\text { premises, are not isolated. Insulated } \\
\text { pipelines are not painted twice with an } \\
\text { anticorrosion coating and oil paint. [5.4] } \\
\text { - "Energy Efficiency" stated that the project } \\
\text { provides the achievement of class "B" } \\
\text { energy efficiency level and temperature, } \\
\text { humidity sensors, innovative cooling } \\
\text { techniques, and CO2 detectors are not } \\
\text { used. [5.5] } \\
\text { - An automated information measurement } \\
\text { and control software of the central power } \\
\text { measuring system and LED lighting is } \\
\text { used but, the volume of automatic lighting } \\
\text { control systems is not sufficient. [5.7] }\end{array}$ & $\begin{array}{l}\text { - "Energy Efficiency" stated that the project } \\
\text { does not provide an energy level and } \\
\text { temperature, humidity sensors, innovative } \\
\text { cooling techniques, and } \mathrm{CO}_{2} \text { detectors are not } \\
\text { used. [5.5] } \\
\text { - HVAC systems use ozone-friendly refrigerants } \\
\text { and it is shown that the noise from the } \\
\text { equipment does not exceed the established } \\
\text { norms. But, the equipment does not have } \\
\text { voluntary certificates and markings. [5.6] }\end{array}$ \\
\hline $\begin{array}{l}\mathrm{EE} \\
5.4\end{array}$ & $\begin{array}{l}\text { Threats } \\
\text { (EE) }\end{array}$ & - & - \\
\hline
\end{tabular}




\subsubsection{Material and waste (MW)}

Material related categories possess a great potential to improve the green building levels. Gurgun et al. [32] argued that material related categories are one of the hardest categories to fulfill. This argument could be supported by Table 7 . It could be seen that both projects do not have any strengths in Material and Waste category. It is important to measure the value of the missing points and take relevant precautions. Three subcategories of project A (6.2, 6.3 and 6.5) and five subcategories of project B $(6.1,6.2,6.3,6.4$ and 6.5$)$ could not receive a single point.

Table 7. SWOT analysis of material and waste category

\begin{tabular}{|c|c|c|c|}
\hline No & $\begin{array}{l}\text { SWOT } \\
\text { (Category) }\end{array}$ & Project A [Subcategory] & Project B [Subcategory] \\
\hline $\begin{array}{l}\text { MW } \\
6.1\end{array}$ & $\begin{array}{l}\text { Strengths } \\
\text { (MW) }\end{array}$ & - & - \\
\hline $\begin{array}{l}\text { MW } \\
6.2\end{array}$ & $\begin{array}{l}\text { Weaknesse } \\
\text { s (MW) }\end{array}$ & $\begin{array}{l}\text { - No renewable raw materials are used. [6.2] } \\
\text { - No use of the construction and finishing of } \\
\text { certified wood and wood products. [6.3] } \\
\text { - The preservation and use of existing walls } \\
\text { etc. are not possible as the project is not } \\
\text { reconstructed. [6.5] }\end{array}$ & $\begin{array}{l}\text { - No construction materials produced in } \\
\text { the region. [6.1] } \\
\text { - No renewable raw materials are used. } \\
\text { [6.2] } \\
\text { - No use of the construction and finishing } \\
\text { of certified wood and wood products. } \\
\text { [6.3] } \\
\text { - No use and recycle of waste produced } \\
\text { during the demolition and construction } \\
\text { of buildings or from consumer or } \\
\text { industrial waste. [6.4] } \\
\text { - The preservation and use of existing } \\
\text { walls etc. are not possible as the project } \\
\text { is not reconstructed. [6.5] }\end{array}$ \\
\hline $\begin{array}{l}\text { MW } \\
6.3\end{array}$ & $\begin{array}{l}\text { Opportunit } \\
\text { ies (MW) }\end{array}$ & $\begin{array}{l}\text { - Building and finishing materials are } \\
\text { certified and environmentally labeled. } \\
\text { However, no VOC air quality analysis is } \\
\text { made. [6.6] } \\
\text { - Storage and separate collection of solid } \\
\text { waste are provided, but organizational } \\
\text { works are not completed. Also, no } \\
\text { automated tools for the collection and } \\
\text { disposal of solid waste. [6.8] }\end{array}$ & $\begin{array}{l}\text { - Separate collection of solid waste is } \\
\text { provided, but the waste is not } \\
\text { transferred to recycling. Automated } \\
\text { tools for the collection and disposal of } \\
\text { solid waste are available. But solid } \\
\text { waste disposal program within the } \\
\text { existing infrastructure is not ready. } \\
\text { [6.8] }\end{array}$ \\
\hline $\begin{array}{l}\text { MW } \\
6.4\end{array}$ & $\begin{array}{c}\text { Threats } \\
(\mathrm{MW})\end{array}$ & $\begin{array}{l}\text { - Only a small part of the construction } \\
\text { materials produced in the region }(0-\% 10) \text {. } \\
\text { [6.1] } \\
\text { - Industrial wastes are used in the } \\
\text { construction of a mineral insulation total } \\
\text { cost of materials (over } \% 5) \text { but, no use and } \\
\text { recycle of waste produced during the } \\
\text { demolition and construction of buildings. } \\
{[6.4]} \\
\text { - Food waste is offered stored in plastic bags } \\
\text { in special refrigerators, and then export to } \\
\text { landfills but it is not ensured that food } \\
\text { waste is in tightness gathering places. [6.7] }\end{array}$ & $\begin{array}{l}\text { - Building and finishing materials are } \\
\text { certified but not environmentally } \\
\text { labeled. Also, no VOC air quality } \\
\text { analysis is made. [6.6] } \\
\text { - It is not ensured that food waste is in } \\
\text { tightness gathering places. [6.7] }\end{array}$ \\
\hline
\end{tabular}




\subsubsection{Quality and comfort of the environment (QC)}

Human comfort is one of the most prominent necessities to be fulfilled in green building certification systems [33]. Another characteristic of Ecostandart that is separated from other certification systems is the importance given to measuring electromagnetic and ionizing radiation levels where the density of this kind of waves are raising with the developing technology. In the Ecostandard certification, design solutions in order to reduce the impact of electromagnetic, ionizing radiation and radon levels inside the property, and vibration, electromagnetic radiation, and ionizing radiation measures are not provided in both projects. On the other hand, instrumental monitoring of the drinking water quality and purification, metering systems for the heating and lighting sources are found as the strengths for both projects. Project B, could not receive any points from subcategory 7.4 which refers to the control of noise and vibration related pollutions.(Table 8)

Table 8. SWOT analysis of quality and comfort of the environment category

\begin{tabular}{|c|c|c|c|}
\hline No & $\begin{array}{l}\text { SWOT } \\
\text { (Category) }\end{array}$ & Project A [Subcategory] & Project B [Subcategory] \\
\hline $\begin{array}{l}\text { QC } \\
7.1\end{array}$ & $\begin{array}{l}\text { Strengths } \\
\text { (QC) }\end{array}$ & $\begin{array}{l}\text { - A total ban on smoking in the building } \\
\text { avoids air pollution inside the property. } \\
\text { [7.2] } \\
\text { - Conducted instrumental monitoring of } \\
\text { drinking water quality, purification of } \\
\text { water solutions could be improved. [7.3] } \\
\text { - Silencers are installed in the air ducts of } \\
\text { ventilation systems, to exclude the spread } \\
\text { of structural noise vibration isolation } \\
\text { equipment is used, vibration control } \\
\text { materials are used. [7.4] } \\
\text { - The necessary parameters of microclimate } \\
\text { in the premises are provided an automatic } \\
\text { control of the heat transfer and heating } \\
\text { systems are equipped with metering } \\
\text { devices, control, and automatic control, the } \\
\text { light level could be controlled in the room. } \\
\text { [7.6] }\end{array}$ & $\begin{array}{l}\text { - A complete ban on smoking in the } \\
\text { building, except the restaurant and } \\
\text { residential apartments. (8 points } \\
\text { achieved) [7.2] } \\
\text { - Conducted instrumental monitoring of } \\
\text { drinking water quality, purification of } \\
\text { water solutions could be improved. } \\
\text { [7.3] } \\
\text { The necessary parameters of } \\
\text { microclimate in the premises are } \\
\text { provided an automatic control of the } \\
\text { heat transfer and heating systems are } \\
\text { equipped with metering devices, } \\
\text { control, and automatic control. } \\
\text { Illumination is regulated by dimmers. } \\
\text { Luminaires can be turned on. At the } \\
\text { workplace, there is local lighting. [7.6] }\end{array}$ \\
\hline $\begin{array}{l}\text { QC } \\
7.3\end{array}$ & $\begin{array}{l}\text { Weaknesse } \\
\text { s (QC) }\end{array}$ & $\begin{array}{l}\text { - Design solutions in order to reduce the } \\
\text { impact of electromagnetic, ionizing } \\
\text { radiation and radon levels inside the } \\
\text { property are not provided. [7.5] }\end{array}$ & $\begin{array}{l}\text { - In the premises, no design solutions to } \\
\text { reduce the noise and vibration level to } \\
\text { a comfortable level are used. [7.4] } \\
\text { - Design solutions in order to reduce the } \\
\text { impact of electromagnetic, ionizing } \\
\text { radiation and radon levels inside the } \\
\text { property are not provided. [7.5] } \\
\text { - The analysis and the evaluation of } \\
\text { potential sources of external } \\
\text { contamination, soil, air and noise } \\
\text { pollution control at the construction } \\
\text { site and minimization measures are } \\
\text { taken. However, vibration, } \\
\text { electromagnetic radiation and ionizig } \\
\text { radiation measures are not taken. [7.1] }\end{array}$ \\
\hline $\begin{array}{l}\text { QC } \\
7.4\end{array}$ & $\begin{array}{l}\text { Threats } \\
\text { (QC) }\end{array}$ & $\begin{array}{l}\text { - The analysis and the evaluation of potential } \\
\text { sources of external contamination and soil } \\
\text { pollution control at the construction site } \\
\text { and minimization measures are taken. } \\
\text { However, noise, air pollution, vibration, } \\
\text { electromagnetic radiation, and ionizing } \\
\text { radiation measures are not taken. [7.1] }\end{array}$ & 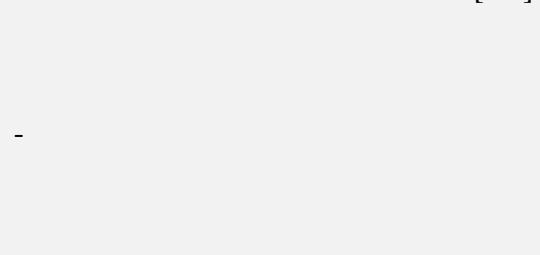 \\
\hline
\end{tabular}




\subsubsection{Health and safety (HS)}

Health and Safety related measures are essential components of the buildings. Moreover, maintaining a healthy interior and exterior climate for their occupants is one of the prominent aims of green buildings. Other than national regulations and standards, green buildings tend to create safer living spaces considering various unwanted situations such as power or water cuts, floods, fire, deterioration of air or water quality, etc. In the case studies, an independent power supply and especially an independent water source need to be handled wisely. Both projects did not show weakness in this category. (Table 9)

\section{Discussion}

Site selection, Infrastructure and Landscaping category is found as the most successful category, where architectural planning and design solutions category is found as the category which contributed the most for the success of both projects because of its potential points. On the other hand, material and waste category is found as the least successful category, where health and safety is the category with the least contributed to the total points because of its lower level of potential points. Over $30 \%$ of the remaining points are due to deficiencies in the material and waste category for both projects, where only $6 \%$ of the remaining points are originated from the inadequacy of health and safety category.

Table 9. SWOT Analysis of Health and Safety Category

\begin{tabular}{|c|c|c|c|}
\hline No & $\begin{array}{l}\text { SWOT } \\
\text { (Category) }\end{array}$ & Project A [Subcategory] & Project B [Subcategory] \\
\hline $\begin{array}{l}\mathrm{HS} \\
8.1\end{array}$ & $\begin{array}{l}\text { Strengths } \\
\text { (HS) }\end{array}$ & - Alarm systems are placed and optimized. [8.3] & \\
\hline $\begin{array}{l}\mathrm{HS} \\
82\end{array}$ & $\begin{array}{l}\text { Weaknesse } \\
\text { (HS) }\end{array}$ & - & - \\
\hline $\begin{array}{l}\mathrm{HS} \\
8.3\end{array}$ & $\begin{array}{l}\text { Opportunit } \\
\text { ies (HS) }\end{array}$ & - Installed hazardous gas detectors ( $\mathrm{CO}$ ) only in & he parking lot. [8.1] \\
\hline $\begin{array}{l}\text { HS } \\
8.4\end{array}$ & $\begin{array}{l}\text { Threats } \\
\text { (HS) }\end{array}$ & $\begin{array}{l}\text { - An independent source of the power supply is } \\
\text { present. According to the degree of reliability of } \\
\text { power supply of the building electrical receivers } \\
\text { are Grade II, battery hour is not less than } 3 \\
\text { hours. But there is no presence of independent } \\
\text { water source. [8.2] }\end{array}$ & $\begin{array}{l}\text { - The power supply is produced from two } \\
\text { substations of different suppliers, so } \\
\text { minimizes the possibility of complete power } \\
\text { cuts. Also, the facility uses a diesel } \\
\text { generator set for emergency situations } \\
\text { (designed only to maintain sources of } \\
\text { category } 1 \text {, fire elevators, fire extinguishing } \\
\text { system, ITP, etc.) But there is no presence } \\
\text { of independent water source. [8.2] }\end{array}$ \\
\hline
\end{tabular}
of the first four categories are found by the differences in RSP 3.2 - Smart controllers, plants that do not require watering or technology for the minimization of drinking water consumption is implemented in project $B, \mathrm{AD} 4.1$ - The property is integrated into the existing landscape in project $B$, AD 4.3 - Night-light escape is restricted in project A, AD 4.8 - Architectural and design solutions for noise pollution are provided in project $B$, and SIL 2.8 - Greening level of the roof is $37 \%$ in project $B$. A system for collecting stormwater, wastewater treatment for landscape irrigation has not been introduced for both projects.

According to Fig. 4, the inadequacy of the Material and Waste category is obvious for both projects. However, project A performed better in MW 6.4 by - Industrial wastes are used in the construction of mineral insulation more than $5 \%$ of the total cost of materials and MW 6.1 - A small part of the construction materials produced in the region $(0$ \%10). QC 7.4 - Silencers in the air ducts of ventilation systems, structural noise vibration isolation equipment, and vibration control materials are used in project $A$ which is the greatest difference of these two projects. Lack of renewable raw materials use [6.2], construction and finishing of certified wood and wood products [6.3] and the preservation and use of existing walls, etc. are not possible as the project is not reconstructed [6.5] are the common weaknesses of these project in Ecostandard certification. 
틀 $\mathrm{A}$ 틀

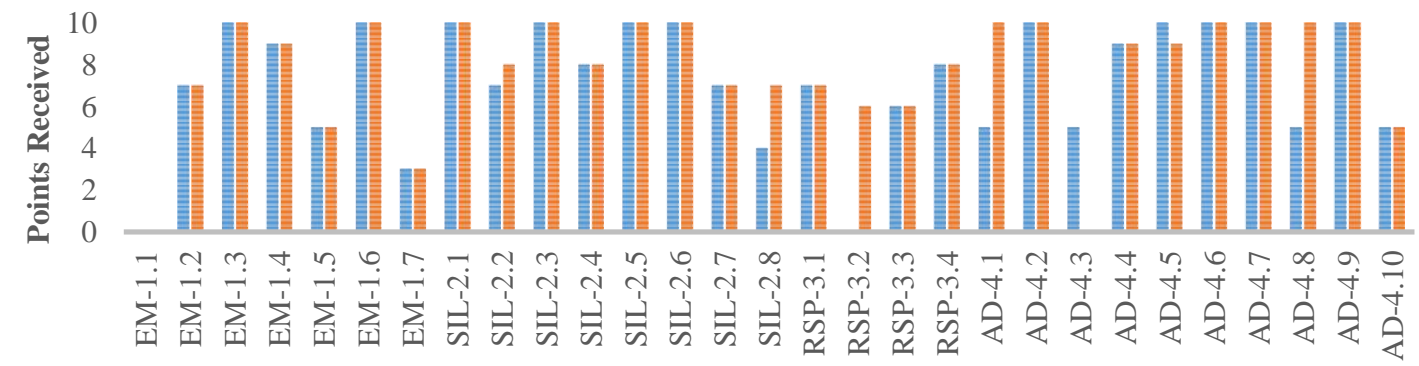

Subcategories

Fig. 3. Final merged scorecard for both projects (categories 1-4)

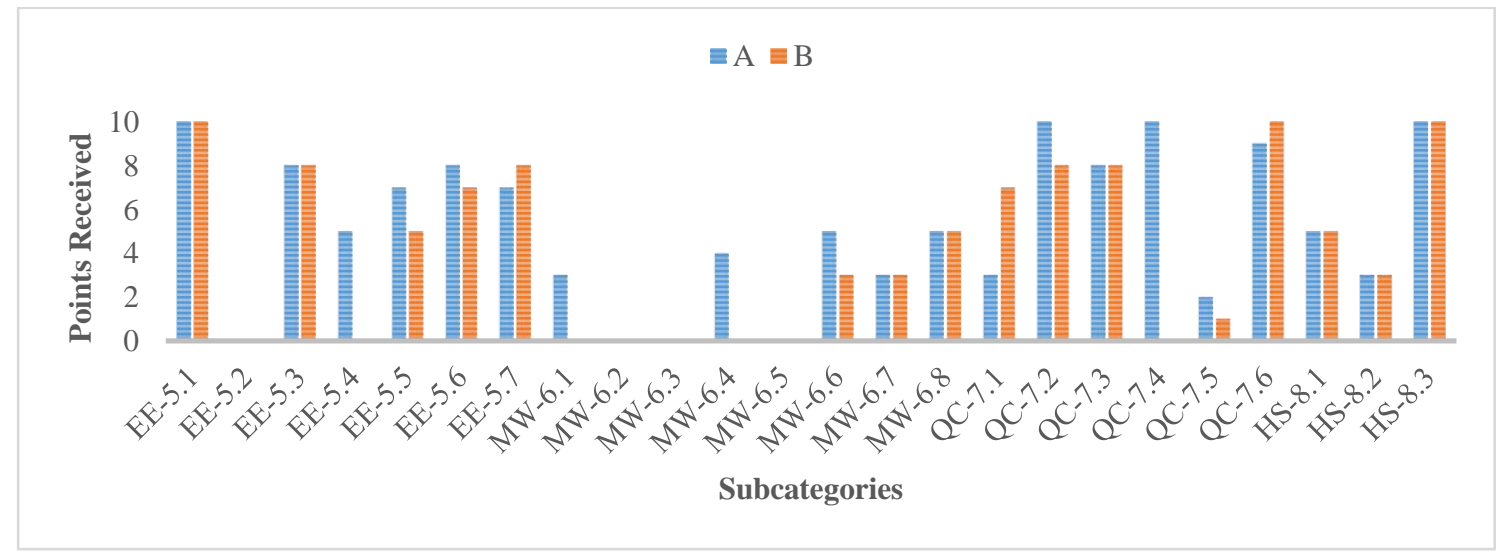

Fig. 4. Final merged scorecard for both projects (categories 5-8)

A limited number of projects, using one foreign contractor and one local certification system in the capital city with better economical and logistic related conditions, interviewing with only one representative from the certification body could be considered as the main limitations of this study. Therefore, the results of this study are specific to the projects considered and cannot be generalized for all of green building certified projects undertaken by foreign contractors in Russia.

\section{Conclusions}

Construction is an activity that significantly affects the environment. Green building certification systems developed for the intelligent use of the land, materials, water, and energy have begun to guide the construction sector with innovative solutions in the last decades. In Russia, which is a developing country that sets sustainable development targets, the importance of green building construction techniques is increasing. In this study, two shopping mall projects undertaken by a foreign contractor in Russia are examined according to the Ecostandard certification system. Scorecards of two projects were analyzed by a novel SWOT analysis method and the reasons why project A and B couldn't receive a single point respectively in 6 and 9 subcategories are explained according to the interviews with industry professionals. In the two projects, the Site selection, Infrastructure, and Landscaping category is the most successful, while the material and waste category is the most unsuccessful category. 
Therefore, it is necessary to give greater emphasis on the use of renewable raw materials and certified wood as well as the protection of existing structures (in case of a renovation project). Thus, in addition to the strengths and weaknesses, the type of threats and opportunities in future projects are explained categorically and in detail. This study is carried out to guide contractors who want to receive green building certification while building a commercial building in a foreign country. One limitation of this study is its limited number of projects to be considered that is undertaken by the same contractor firm. Also, both shopping malls are constructed in Moscow city, which does not represent the similar characteristics of the smaller Russian towns or rural areas.

The study can be further developed with calculating the concepts such as cost over time and life-cycle-assessment related calculations. Also, the study could be conducted with greater data, for a different type of certified structure, in a different developing country by multiple contractors and with a different certification system.

\section{Acknowledgments}

The authors would like to express their gratitude to ENKA Design Center; Fatma Olcay Ertürk, Engin Özbıyık, Bülent Göktaş, Mehmet Batıkan Arısoy and Ecostandard group for their insightful contributions.

\section{References}

[1] Kucukvar M, Tatari O (2013). Towards a triple bottom-line sustainability assessment of the US construction industry. The International Journal of Life Cycle Assessment, 18(5): 958-972.

[2] Nejat P, Jomehzadeh F, Taheri MM, Gohari M, Majid MZ (2015). A global review of energy consumption, $\mathrm{CO} 2$ emissions and policy in the residential sector (with an overview of the top ten $\mathrm{CO} 2$ emitting countries). Renewable and sustainable energy reviews, 43, 843-862.

[3] Durdyev S, Zavadskas E, Thurnell D, Banaitis A, Ihtiyar A (2018). Sustainable construction industry in Cambodia: Awareness, drivers and barriers. Sustainability, 10(2): 392.
[4] Baniassadi A, Heusinger J, Sailor DJ (2018). Building energy savings potential of a hybrid roofing system involving high albedo, moisture retaining foam materials. Energy and Buildings, 169: 283-294.

[5] Babatunde SO, Awodele OA, Adeniyi O (2018). Opportunities and challenges of foreign direct investment utilisation and its impact on construction sector in developing countries. Journal of Financial Management of Property and Construction, 23(2): 239-256.

[6] Kumar H, Sahu V (2015). Performance and rating of residential green building. Civil Engineering and Urban Planning: An International Journal (CiVEJ) Vol, 2.

[7] Zhou Y, Shu C, Jiang W, Gao S (2019). Green management, firm innovations, and environmental turbulence. Business Strategy and the Environment, 28(4), 567-581.

[8] Bayhan HG, Gurgun AP. Evaluation of Leed Certified Green Buildings. EURO-MED-SEC-1 The First European and Mediterranean Structural Engineering and Construction Conference, ISEC Press, doi: 10.14455/ISEC.res.2016.100, ISBN: 978-0-9960437-2-4, Istanbul, 2016.

[9] Kibert CJ. Sustainable construction: green building design and delivery. John Wiley \& Sons, 2016.

[10] Wu Z, Li H, Feng Y, Luo X, Chen Q (2019). Developing a green building evaluation standard for interior decoration: A case study of China. Building and Environment, 152, 50-58.

[11] Gul MS, Patidar S (2015). Understanding the energy consumption and occupancy of a multipurpose academic building. Energy and Buildings, 87: 155-165.

[12] Liang Z, Bian D, Zhang X, Shi D, Diao R, Wang Z (2019). Optimal energy management for commercial buildings considering comprehensive comfort levels in a retail electricity market. Applied Energy, 236: 916-926.

[13] Hami A, Moula FF, Maulan SB (2018). Public preferences toward shopping mall interior landscape design in Kuala Lumpur, Malaysia. Urban Forestry \& Urban Greening, 30, 1-7.

[14] Bloomberg (2018). Malaysia Beats Emerging Market Peers as Asia Outshines. Retrieved from https://www.bloomberg.com/news/articles/201811-27/turkey-sinks-to-last-on-emerging-marketscorecard-malaysia-tops on 15.02.2019. 
[15] RT. (2019). Russia overtake Germany. Retrieved from https://www.rt.com/business/448925-russiaovertake-germany-2020/ on 15.02.2019.

[16] Russian Outlook on the New Paradigm for Sustainable Development, Report on Implementing the Principles of Sustainable Development in the Russian Federation, Preparing for "Rio + 20", Moscow, 2012.

[17] Valentik I, Statement by Deputy Minister of Natural Resources and Environment of the Russian Federation, 2018. Retrieved from http://russiaun.ru/en/news/forest080718, on 14.02.2019.

[18] Putin V (2018). Moscow Urban Forum Megacity of the Future: New Space for Living, Retrieved from http://en.kremlin.ru/events/president/news/58026 on 14.02.2019.

[19] Telichenko VI, Potapov AD, Slesarev M-Yu, Shcherbina EV (2009). The ecological safety of construction. Publishing Architecture. Moscow. 311.

[20] Gennadievna-Pahomova E, Tomakov IV, Tomakov VM (2017). The formation of the green building market of the Russian cities. Journal of Applied Engineering Science, 15(3): 395-400.

[21] Martianov V (2016). Green buildings in Russia, environmental classification of buildings.

[22] Fan P, Chen J, Ouyang Z, Groisman P, Loboda T, Gutman G, Myint SW (2018). Urbanization and sustainability under transitional economies: a synthesis for Asian Russia. Environmental Research Letters, 13(9), 095007.

[23] Ecostandard (2019). Ecostandard group, About Us. Retrieved from https://ecostandardgroup.ru/ on 16.02.2019.

[24] Oz O (2001). The competitive advantage of nations: the case of Turkey (Doctoral dissertation, London School of Economics and Political Science (University of London)).

[25] Vainio A (2009). How to Enter the Russian Construction Market: Business Strategies for Oy RVP Niemelä AB.

[26] Wong JKW, San Chan JK, Wadu MJ (2016). Facilitating effective green procurement in construction projects: An empirical study of the enablers. Journal of cleaner production, 135, 859871.

[27] Killen CP, Walker M, Hunt RA (2005). Strategic planning using QFD. International Journal of Quality \& Reliability Management, Vol. 22 No. 1, pp. 17-29
[28] Bell GG, Rochford L (2016). Rediscovering SWOT's integrative nature: A new understanding of an old framework. The International Journal of Management Education, 14(3), 310-326.

[29] Bayhan HG, Karaca E (2019). SWOT Analysis of Biomimicry for Sustainable Buildings-A Literature Review of the Importance of Kinetic Architecture Applications in Sustainable Construction Projects", 2019 IOP Conf. Ser.: Mater. Sci. Eng. $471 \quad 082047$, https://doi.org/10.1088/1757-899X/471/8/082047.

[30] Khoshbakht M, Gou Z, Dupre K (2017). Costbenefit prediction of green buildings: SWOT analysis of research methods and recent applications. Procedia Engineering, 180, 167-178.

[31] Waidyasekara KGAS, De Silva ML, Rameezdeen R. Comparative study of green building rating systems: In terms of water efficiency and conservation. Second World Construction Symposium, Colombo, Sri Lanka, 2013.

[32] Gurgun AP, Polat G, Bayhan HG. Contractor Perspective on Material Risks in Green Building Projects", 12th International Congress on Advances in Civil Engineering (ACE 2016), ISBN 978-975-518-395-4, Istanbul

[33] Cole RJ, Brown Z (2009). Reconciling human and automated intelligence in the provision of occupant comfort. Intelligent buildings international, 1(1), 39-55. 